\title{
RICTOR wt Allele
}

National Cancer Institute

\section{Source}

National Cancer Institute. RICT OR wt Allele. NCI Thesaurus. Code C104736.

Human RICT OR wild-type allele is located in the vicinity of 5p13.1 and is approximately $136 \mathrm{~kb}$ in leng th. This allele, which encodes rapamycin-insensitive companion of mTOR protein, plays a role in nutrient-dependent regulation of cell growth. 